\title{
Pengaruh Model Pembelajaran Generatif Berbasis Lingkungan Terhadap Kompetensi Pengetahuan IPA
}

\author{
Ni Luh Pt. Eka Sari1*, DB.Kt.Ngr. Smara Putra², I.B.G. Surya Abadi³ \\ 1,2,3Jurusan Pendidikan Guru Sekolah Dasar (PGSD), Universitas Pendidikan Ganesha, Singaraja, Indonesia.
}

\author{
A R T I C L E I N F O \\ Article history: \\ Article history: \\ Received 20 February 2018 \\ Received in revised form \\ 6 March 2018 \\ Accepted 19 April 2018 \\ Available online 26 May \\ 2018 \\ Kata Kunci: \\ model pembelajaran \\ generatif, lingkungan, \\ kompetensi pengetahuan \\ $I P A$. \\ Keywords: \\ Generative learning, model, \\ environment, science \\ knowledge competence
}

\begin{abstract}
A B S T R A K
Penelitian ini bertujuan untuk mengetahui pengaruh yang signifikan model pembelajaran generatif berbasis lingkungan terhadap kompetensi pengetahuan IPA pada siswa kelas IV SD Gugus I Gusti Ngurah Rai Denpasar Tahun Ajaran 2017/2018. Jenis penelitian ini adalah Penelitian kuantitatif dengan rancangan nonequivalent control group design. Populasi penelitian ini adalah seluruh siswa kelas IV SD Gugus I Gusti Ngurah Rai Denpasar yang berjumlah 249 orang. Sampel dilakukan dengan teknik random sampling. Sampel dalam penelitian ini adalah siswa kelas IVC SDN 4 Sanur dengan jumlah 33 siswa sebagai kelompok eksperimen dan siswa kelas IV SDN 11 Sanur dengan jumlah 32 siswa sebagai kelompok kontrol. Pengumpulan data dilakukan dengan menggunakan metode tes dalam bentuk tes objektif pilihan ganda biasa. Data yang diperoleh dianalisis menggunakan uji-t. Berdasarkan hasil analisis data gain skor ternormalisasi diperoleh $\mathrm{t}_{\text {hitung }}=$ 3,507 sedangkan pada taraf signifikansi $5 \%$ dan $\mathrm{dk}=63$ diperoleh nilai $t_{\text {tabel }}=2,000$ sehingga $t_{\text {hitung }}=3,507>t_{\text {tabel }}=2,000$. Berdasarkan kriterian pengujian, maka $\mathrm{H}_{0}$ ditolak dan $\mathrm{H}_{\mathrm{a}}$ diterima. Adapun nilai ratarata kompetensi pengetahuan IPA pada kelompok yang dibelajarkan dengan model pembelajaran generatif berbasis lingkungan adalah 51,84 , sedangkan pada kelompok yang dibelajarkan dengan pembelajaran konvensional adalah 33,78 . Berdasarkan hasil tersebut dapat disimpulkan bahwa terdapat pengaruh model pembelajaran generatif berbasis lingkungan terhadap kompetensi pengetahuan IPA siswa kelas IV SD Gugus I Gusti Ngurah Rai Denpasar Tahun Ajaran $2017 / 2018$.
\end{abstract}

\section{A B S T R A C T}

The perpose of to research that there was a significant effect of generative environment-based learning model on science knowledge competence in fourth grade students of SD Gugus I Gusti Ngurah Rai Denpasar Academic Year 2017/2018. The type of this research was quantitative research with nonequivalent control group design. The population of this research was all fourth graders of SD Gugus I Gusti Ngurah Rai which amounts to 249 people. The sample was done by random sampling technique. The sample in this research were the students of grade IVC SDN 4 Sanur with the number of 33 students as experiment group and students of grade IV SDN 11 Sanur with 32 students as control group. The data collected by using the test method in the form of a standard multiple-choice objective test. The data obtained analyzed using the t-test. Based on the result of data analysis gain score normalized obtained thitung $=3,507$ while at significance level $5 \%$ and $\mathrm{dk}=63$ obtain thabel value $=2,000$ so thitung $=3.507>\mathrm{ttabel}=2,000$. Based on the test criteria, $\mathrm{Ho}$ is reject and $\mathrm{Ha}$ accept. The average score of science knowledge competence in the group that is though by the generative model base on the environment is 51.84 , while in the group taught by conventional learning is 33.78. Based on these results it can be concluded that there is influence of environment-based generative learning model to science knowledge competence of student of IV grade SD Gugus I Gusti Ngurah Rai Denpasar academic year 2017/2018 


\section{Pendahuluan}

Pendidikan merupakan salah satu komponen dasar yang sangat penting untuk mencerdaskan kehidupan bangsa dan sebagai penentu dari kualitas suatu bangsa. Kurikulum adalah peran mata pelajaran dan program pendidikan yang diberikan oleh suatu lembaga penyelenggara pendidikan yang berisi rancangan pelajaran yang akan diberikan kepada peserta didik dalam suatu periode/jenjang pendidikan. Secara umum tujuan dari pendidikan yang hendak di capai adalah membentuk manusia seutuhnya yakni dari sumber daya manusianya yang berkualitas baik dalam menghadapi kemajuan ilmu pengetahuan dan ilmu teknologi.

Indonesia di pendidikan sampai saat ini terus diperbaiki oleh pemerintah untuk meningkatkan mutu dan kualitas pendidikan agar lebih baik lagi dari sebelumnya pemerintah telah mengupayakan berbagai cara. Salah satunya adalah pembaharuan dan inovasi kurikulum, yakni lahirnya kurikulum 2013. Selain perubahan kurikulum untuk memajukan mutu pendidikan pemerintah juga melakukan beberapa perbaikan sarana dan prasarana di sekolah-sekolah yaitu dengan memberikan dana BoS (bantuan operasional sekolah) secara langsung kepada sekolah-sekolah. Untuk guru yang mengajar disekolah juga diberikan beberapa syarat oleh pemerintah seperti jenjang minimal pendidikan yang harus ditempuh untuk menjadi seorang guru. Pemerintah juga memberikan seminar-seminar yang bernuansa pendidikan kepada guru yang bertujuan untuk meningkatkan kreatifitas guru dalam proses belajar mengajar, dan beberapa upaya lainnya yang telah dilakukan oleh pemerintah.

Berdasarkan hasil observasi yang dilakukan pada tanggal 11 Januari 2018 dengan guru kelas IV di masing-masing SD Gugus I Gusti Ngurah Rai Denpasar Selatan. Pada kompetensi pengetahuan pada muatan pembelajaran IPA yang diperoleh siswa belum optimal. Hal ini disebabkan oleh pembelajaran yang masih berpusat pada guru sehingga pembelajaran kurang menarik dan cenderung monoton. Model pembelajaran seperti ini mengakibatkan kurangnya partisipasi dari siswa sendiri dan membuat siswa menjadi kurang paham dengan materi yang disampaikan. Hal tersebut akan menimbulkan kebosanan dan kurangnya minat belajar peserta didik pada mata pelajaran IPA yang akan berdampak pada rendahnya penguasaan kompetensi pengetahuan siswa. Permasalahan tersebut menjadikan guru harus selektif dalam memilih model dan metode pembelajaran. Pemilihan metode dan model pembelajaran yang sesuai dengan karakteristik siswa akan dapat mengembangkan kreativitas dan potensi peserta didik seluasluasnya untuk menjadi manusia berkualitas sesuai dengan tujuan pendidikan nasional yang berlandaskan pada kurikulum 2013.

Dari permasalahan tersebut, salah satu model pembelajaran yang dapat mempengaruhi kompetensi IPA siswa menjadi lebih optimal yaitu model pembelajaran generatif. (Suastra, 2017:165) "Model Pembelajaran Generatif merupakan model pembelajaran yang berlandaskan pada pandangan konstruktivisme dalam belajar-mengajar yaitu pandangan yang berpedoman pada asumsi dasar bahwa pengetahuan dibangun dalam pikiran pada saat belajar".

Langkah-langkah pelaksanan model ini Menurut Wena (2014:177) "pembelajaran generatif terdiri atas empat tahap, yaitu 1) Pendahuluan atau disebut tahap eksplorasi, 2) tahap pemfokusan, 3) tantangan atau tahap pengenalan konsep, dan 4) Penerapan Konsep".

Untuk mempermudah siswa dalam mengembangkan gagasan, model pembelajaran generatif berbasis lingkungan yakni pembelajaran yang menekankan pada proses pembelajaran siswa sendirilah yang lebih aktif secara mental membangun pengetahuannya, dibantu dengan sumber belajar yaitu lingkungan yang terdapat pada alam sekitar siswa.

"Lingkungan merupakan sumber belajar yang paling efektif dan efisien serta tidak membutuhkan biaya yang besar dalam meningkatkan motivasi belajar peserta didik" (Uno \& Nurdin, 2015:137). Dengan demikan lingkungan merupakan salah satu potensi yang diciptakan oleh Tuhan untuk digunakan sebagai pemenuhan kebutuhan manusia dalam menjalani hidup di dunia yang perlu dijaga kelestariannya. Kelebihan dari penggunaan lingkungan sebagai sumber belajar peserta didik dibawa langsung ke dalam dunia yang konkret tentang penanaman konsep pembelajaran, sehingga peserta didik tidak hanya bisa untuk mengkhayalkan materi. Selain itu, lingkungan juga dapat digunakan setiap saat, kapanpun dan di manapun sehingga tersedia setiap saat, tetapi tergantung dari jenis materi yang sedang diajarkan. Jadi menggunakan lingkungan sebagai media belajar dapat memotivasi belajar peserta didik lebih bertambah karena peserta didik mengalami suasana belajar yang berbeda dari biasanya dan berhadapan langsung dengan alam.

Adapun kelebihan dari model pembelajaran generatif (Wena 2014:184) yaitu sebagai berikut: 1) Memberikan kesempatan kepada siswa untuk mengungkapkan pikiran/pendapat/ pemahamannya terhadap konsep, 2) Melatih siswa untuk mengkomunikasikan konsep,3) Melatih siswa untuk menghargai gagasan orang lain, 4) Memberikan kesempatan kepada siswa untuk perduli terhadap konsepsi awalnya (terutama siswa yang miskonsepsi), siswa diharapkan menyadari miskonsepsi yang terjadi dalam 
pikirannya dan bersedia memperbaiki miskonsepsi tersebut, 5) Memberikan kesempatan kepada siswa untuk mengkonstruksi pengetahuannya sendiri, 6) Dapat menciptakan suasana kelas yang aktif karena siswa dapat membandingkan gagasannya dengan gagasan siswa lainnya serta intervensi guru, 7) Guru mengajar menjadi kreatif dalam mengarahkan siswanya untuk mengkonstruksi konsep yang akan dipelajari, 8) Guru menjadi terampil dalam memahami pandangan siswa, dan mengorganisasi pembelajaran.

Pembelajaran konvensional adalah pembelajaran yang biasa digunakan guru dalam proses pembelajaran sehari - hari serta pembelajaran yang sifatnya masih umum. Pembelajaran konvensional dalam kurikulum 2013 menggunakan pembelajaran dengan pendekatan saintifik. Menurut Kosasih (2016:72) Pendekatan Saintifik merupakan "Pendekatan di dalam kegiatan pembelajaran yang mengutamakan kreatifitas dan temuan-temuan siswa".

Pembelajaran konvensional dalam penelitian ini adalah pendekatan saintifik yang biasa diterapkan oleh guru pada proses pembelajaran dalam kurikulum 2013. Maka dari itu, pada kurikulum 2013 mengamanatkan esensi pendekatan ilmiah dalam pembelajaran yang meliputi kegiatan mengamati, menanya, mengumpulkan informasi, mengasosiasi, dan mengkomunikasikan. Menurut Kosasih (2014:51) "pendekatan saintifik merupakan pendekatan di dalam kegiatan pembelajaran yang mengutamakan kreativitas dan temuan-temuan siswa".

Pembelajaran konvensional dalam penelitian ini adalah pendekatan saintifik yang biasa diterapkan oleh guru pada proses pembelajaran dalam kurikulum 2013. Maka dari itu, pada kurikulum 2013 mengamanatkan esensi pendekatan ilmiah dalam pembelajaran yang meliputi kegiatan mengamati, menanya, mengumpulkan informasi, mengasosiasi, dan mengkomunikasikan. Menurut Kosasih (2014:51) "pendekatan saintifik merupakan pendekatan di dalam kegiatan pembelajaran yang mengutamakan kreativitas dan temuan-temuan siswa".

"Kompetensi merupakan suatu perpaduan dari pengetahuan, keterampilan, nilai dan sikap yang direfleksikan dalam kebiasaan berpikir dan bertindak yang harus dimiliki oleh peserta didik sehingga peserta didik dapat melaksanakan tugas-tugas pembelajaran sesuai dengan jenis pekerjaan tertentu" (Mulyasa, 2015:66). Kompetensi pengetahuan mengukur kemampuan siswa dalam memahami dan menguasai isi dari suatu materi pelajaran setelah memperoleh pengalaman belajar.

Kompetensi pengetahuan IPA adalah penguasaan pengetahuan yang mempelajari tentang fakta serta gejala alam dan proses didalamnya mencakup dimensi pengetahuan yang meliputi ingatan, pemahaman, penerapan, analisis, sintesis, dan evaluasi yang diukur dengan tes kompetensi pengetahuan IPA.

\section{Metode}

Penelitian ini dikategorikan ke dalam penelitian eksperimen karena karakteristik dari penelitian eksperimen adalah variabel bebas yang dimanipulasi, mengontrol variabel serta melakukan observasi. Jakni (2016:1) menyatakan "Penelitian eksperimen merupakan suatu penelitian yang mencoba untuk mencari hubungan sebab akibat antara variabel bebas dan variabel terikat, dimana variabel bebas sengaja dikendalikan dan dimanipulasi (dibedakan perlakuan)".

Penelitian ini akan dilaksanakan pada semester 2 tahun pelajaran 2017/2018 di kelas IV SD Gugus I Gusti Ngurah Rai Kecamatan Denpasar Selatan. Penelitian ini bertujuan untuk mengetahui kompetensi pengetahuan IPA antara kelompok siswa yang dibelajarkan dengan model pembelajaran generatif berbasis lingkungan dengan kelompok siswa yang dibelajarkan dengan pembelajaran konvensional. Rancangan penelitian yang digunakan dalam penelitian ini adalah Nonequivalent Control Grup Design. Rancangan penelitian ini dikategorikan sebagai rancangan eksperimen kuasi (quasi experimental design). Desain penelitian ini digambarkan sebagai berikut.

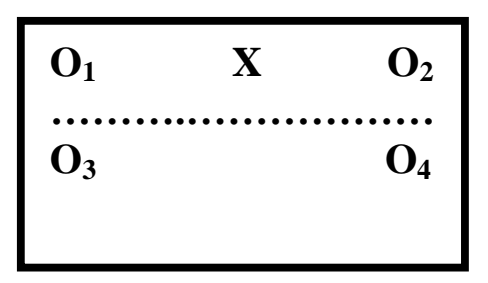

Gambar.1 Nonequilevalent Control Group Design

(Sumber : Sugiyono, 2012:79) 
Populasi adalah semua anggota kelompok manusia, binatang, peristiwa, atau benda yang tinggal bersama dalam satu tempat dan secara terencana menjadi target kesimpulan dari hasil akhir suatu penelitian" Sukardi (2011:53). Berdasarkan pernyataan dari ketua gugus I Gusti Ngurah Rai, dinyatakan bahwa seluruh siswa kelas IV SD Gugus I Gusti Ngurah Rai setara secara akademik, sehingga tidak terdapat kelas unggulan. Populasi dalam penelitian ini adalah seluruh siswa kelas IV Sekolah Dasar Gugus I Gusti Ngurah Rai Denpasar Tahun Ajaran 2017/2018 yang berjumlah 249 siswa.

Sampel adalah sebagian dari populasi yang diambil, yang dianggap mewakili seluruh populasi dan diambil dengan menggunakan teknik tertentu" (Agung, 2014:69). Pemilihan sampel penelitian ini tidak dilakukannya pengacakan individu, karena tidak bisa mengubah kelas yang telah terbentuk sebelumnya. Kelas yang dipilih telah terbentuk tanpa campur tangan peneliti dan tidak dilakukannya pengacakan individu, kemungkinan pengaruh-pengaruh dari keadaan subjek mengetahui dirinya dilibatkan dalam eksperimen dapat dikurangi sehingga penelitian ini benar-benar menggambarkan pengaruh perlakuan yang diberikan.

Teknik atau cara untuk menentukan sampel yaitu dengan memberikan nomor urut pada setiap SD yang ada di Gugus I Gusti Ngurah Rai kemudian dilakukan rondom sampling. Menurut Darmadi (2013:49) "Random Smpling/sampling acak adalah elemen sampling dimana elemen sampelnya ditentukan berdasarkan nilai probabilitas dan pemiluhannya dilakukan secara acak". Berdasarkan hasil random, didapatkan dua kelas dari 5 SD Negeri yang terpilih sebagai sampel. Setelah itu akan diuji kesetaraan sampel menggunakan uji-t. Jika keadaan sampel setara, maka akan dilanjutkan dengan menentukan 1 kelas eksperimen dan 1 kelas kontrol.

Pada tahap pertama dilakukan teknik pengambilan sampel dengan cara undian, sehingga semua anggota populasi memiliki kesempatan yang sama untuk menjadi sampel penelitian. Cara udian dilakukan dengan memberikan nomor urut di seluruh SD populasi pada masing-masing kertas yang jumlahnya 7 kelas. Kemudian kertas digulung dan dimasukan ke dalam kotak dan dikocok. Kemudian diambil gulungan kertas yang telah dikocok, undian yang keluar pertama dipilih sebagai kelas eksperimen dan undian yang keluar kedua sebagai kelas kontrol.

Pada tahap kedua, untuk mendapatkan kelas yang setara dari segi akademik, dua kelas terpilih melalui pengundian dilakukan uji kesetaraan sampel dengan diberikan pre test, nilai atau skor dari hasil pre test yang dilakukan tersebut untuk mengetahui tingkat kesetaraan sampel. Nilai satau skor hasil pre tes tersebut diuji kesetaraanya menggunakan uji-t. Sebelum menggunakan uji-t terlebih dahulu dilakukan uji persyaratan yang meliputi uji normalitas dan uji homogenitas varian. Kesetaraan sampel diuji dengan rumus uji-t yakni dengan polled varians.

Penelitian ini melibatkan variabel bebas dan variabel terikat. Menurut Setyosari (2015:165) "variabel bebas adalah variabel yang menyebabkan atau mempengaruhi, yaitu faktor-faktor yang diukur, dimanipulasi, atau dipilih oleh peneliti untuk menentukan hubungan antara fenomena yang diobservasi atau diamati". Variabel bebas dalam penelitian ini adalah Model Pembelajaran Generatif Berbasis Lingkungan. Menurut Setyosari (2015:165) "variabel terikat adalah faktor-faktor yang diobservasi dan diukur untuk menentukan adanya pengaruh variabel bebas, yaitu faktor yang muncul, atau tidak muncul, atau berubah sesuai dengan yang diperkenalkan oleh peneliti itu". Variabel terikat dalam penelitian ini adalah Kompetensi Pengtahuan IPA siswa.

Instrumen yang digunakan untuk mengumpulkan data tentang kompetensi pengetahuan IPA siswa adalah tes kompetensi pengetahuan IPA siswa. Instrumen yang digunakan untuk mengumpulkan data kompetensi pengetahuan IPA adalah tes objektif dalam bentuk pilihan ganda biasa (Multiple Choice Test) dengan 4 pilihan jawaban (Suharsimi, 2015:183) menyatakan "Multiple choice test terdiri atas suatu keterangan atau pemberitahuan tentang suatu pengertian yang belum lengkap dan untuk melengkapinya harus memilih satu dari beberapa kemungkinan jawaban yang telah disediakan". Multiple choice test terdiri atas bagian keterangan (stem) dan bagian kemungkinan jawaban atau alternatif (options). Kemungkinan jawaban (option) terdiri atas satu jawaban yang benar yaitu kunci jawaban dan beberapa pengecoh (distractor).

\section{Hasil dan Pembahasan}

Mean data kompetensi pengetetauan IPA siswa pada kelompok eksperimen $=51,84$ lebih dari mean data kompetensi pengetahuan IPA siswa pada kelompok kontrol $=33,78$. Uji prasyarat dilakukan terlebih dahulu sebelum uji hipotesis menggunakan uji-t. Uji prasyarat tersebut meliputi uji normalitas dan uji homogenitas varians diuraikan berikut ini. Uji normalitas dilakukan untuk mengetahui sebaran frekuensi skor pada setiap variabel berdistribusi normal atau tidak. Untuk menguji data kompetensi pengetahuan IPA siswa kelompok eksperimen dan kontrol dengan menggunakan analisis Chi Kuadrat 
dengan rumus $X_{\text {hit }}^{2}=\sum_{i=1}^{k} \frac{\left(f_{0}-f_{h}\right)^{2}}{f_{h}}$. Kriteria pengujian pada uji normalitas adalah jika $\mathrm{x}^{2}{ }_{\text {hitung }}<\mathrm{x}^{2}$ tabel dengan derajat kebebasan $(\mathrm{dk})=\mathrm{k}-1=6-1=5$, maka diperoleh $X_{\text {tabel }}^{2}=11,070$ maka sebaran data kedua kelompok berdistribusi normal.

Berdasarkan hasil uji normalitas Pada kelompok eksperimen diperoleh Chi Kuadrat hitung $\left(x^{2}\right.$ hitung $\left.=1,36\right)$ kemudian nilai tersebut dibandingkan dengan Chi Kuadrat tabel $\left(x^{2}\right.$ tabel $\left.=11,070\right)$. Hal ini menunjukkan bahwa $\mathrm{x}^{2}$ hitung $<\mathrm{x}^{2}$ tabel berarti data kompetensi pengetahuan IPA siswa kelompok eksperimen berdistribusi normal

Pada kelompok kontrol diperoleh Chi Kuadrat hitung $\left(x^{2}\right.$ hitung $\left.=1,93\right)$ kemudian nilai tersebut dibandingkan dengan Chi Kuadrat tabel $\left(\mathrm{x}^{2}\right.$ tabel $\left.=11,070\right)$. Hal ini menunjukkan bahwa $\mathrm{x}^{2}$ hitung $<\mathrm{x}^{2}$ tabel berarti data kompetensi pengetahuan IPA siswa kelompok kontrol berdistribusi normal. Berdasarkan paparan tersebut maka dinyatakan kelompok eksperimen dan kelompok kontrol berdistribusi normal.

Pengujian homogenitas varians antar kelompok dimaksudkan untuk meyakinkan bahwa perbedaan yang diperoleh uji-t benar - benar berasal dari perbedaan antar kelompok bukan disebabkan oleh perbedaan di dalam kelompok. Pengujian homogenitas varians bertujuan agar sampel yang diambil benar - benar representatif. Sampel yang representatif adalah sampel yang benar - benar dapat mewakili dari seluruh populasi dan dapat bersifat homogen. Uji homogenitas varians dapat dilakukan apabila kelompok data tersebut dalam distribusi normal. Uji homogenitas varians menggunakan uji Fisher (F) dengan rumus :

$$
\begin{gathered}
F_{\text {hitung }}=\frac{\text { Varians terbesar }}{\text { Varians terkecil }} \\
F_{\text {hit }}=\frac{554,55}{324,82}=1,71
\end{gathered}
$$

Apabila $F_{\text {hitung }}<F_{\text {tabel, }}$, maka sampel homogen. Pengujian dilakukan pada taraf signifikansi $5 \%$ dengan derajat kebebasan (dk1) untuk pembilang n1-1 dan derajat kebebasan (dk2) untuk penyebut n2-1. Dari hasil perhitungan diperoleh Fhitung $=1,71$, harga ini kemudian dibandingkan dengan harga Ftabel dengan derajat kebebasan pembilang $=33-1=32$ dan derajat kebebasan penyebut $=32-1=31$ dengan taraf signifikasi 5\%, sehingga diperoleh Ftabel= 1,82. Karena harga Fhitung< Ftabel $(1,71<1,82)$. Ini berarti varians data kompetensi pengetahuan IPA antara kelompok eksperimen kelas IVC SDN 4 Sanur dan kelompok kontrol kelas IV SDN 11 Sanur adalah homogen. Pada penelitian ini, yang diuji adalah hipotesis nol (H0). Adapun hipotesis nol yang diajukan adalah tidak terdapat pengaruh yang signifikan model pembelajaran generatif berbasis lingkungan terhadap kompetensi pengetahuan IPA pada siswa kelas IVC SD Gugus I Gusti Ngurah Rai Denpasar Tahun Pelajaran 2017/2018. Hasil uji prasyarat yang meliputi uji normalitas dan homogenitas varians yang dilakukan dalam penelitian ini diperoleh kedua kelompok sampel berdistribusi normal dan memiliki varians yang homogen. Analisis statistik yang digunakan untuk menguji hipotesis penelitian ini adalah uji-t dengan volled varians. Rekapitulasi hasil analisis uji-t kelompok sampel penelitian ini disajikan dalam tabel 3. berikut ini.

\begin{tabular}{|c|c|c|c|c|c|c|c|}
\hline No & Kelompok Sampel & $\mathrm{N}$ & $\mathrm{Dk}$ & $\bar{X}$ & $\mathrm{~S}^{2}$ & $\mathrm{t}_{\text {hitung }}$ & $\overline{t_{\text {tabel }}}$ \\
\hline 1. & Eksperimen & 33 & 63 & 51,84 & 554,55 & 3,507 & 2,000 \\
\hline 2. & Kontrol & 32 & & 33,78 & 324,82 & & \\
\hline
\end{tabular}

Tabel 1. Rekapitulasi Hasil Analisis Uji-t Kelompok Sampel Penelitian

Analisis uji-t untuk data kompetensi pengetahuan IPA siswa dapat dilihat pada lampiran. Dari rekapitulasi hasil perhitungan menunjukkan thitung $=3,507$ dan ttabel $=2,000$ untuk $\mathrm{dk}=\mathrm{n} 1+\mathrm{n} 2-2=63$ dengan taraf signifikansi 5\%. Berdasarkan kriteria pengujian, karena thitung $>$ ttabel maka H0 ditolak dan Ha diterima. Maka dapat disimpulkan bahwa terdapat pengaruh yang signifikan model pembelajaran 
generatif berbasis lingkungan terhadap kompetensi pengetahuan IPA pada siswa kelas IV SD Gugus I Gusti Ngurah Rai Denpasar Tahun Ajaran 2017/2018.

Pada kelompok eksperimen, kegiatan pembelajaran dalam mata pelajaran IPA menggunakan model pembelajaran generatif berbasis lingkungan berjalan dengan optimal dan kondusif. Hal ini disebabkan karena dengan menerapkan model pembelajaran generatif berbasis lingkungan siswa diberikan kesempatan untuk terlibat aktif, tidak hanya mendengar keterangan guru tetapi berperan aktif untuk menggali, menganalisis, mengevaluasi pemahamannya terhadap konsep yang dipelajari. Selain itu pembelajaran yang dilakukan secara berkelompok juga sangat membantu siswa dalam menumbuhkan orisinilitas ide, kreatifitas, kognitif tinggi, kekritisan pemikiran siswa, komunikasi-interaksi, sharing, keterbukaan, dan sosialisasi dalam diskusi yang dilakukan dalam kelompok. Dengan dihadapkannya siswa terhadap masalah kontekstual dalam pembelajaran IPA juga menjadikan proses pembelajaran menjadi lebih bermakna, karena apa yang dipelajari siswa menyangkut kepada masalah yang kerap kali ditemui oleh siswa dalam kehidupan nyata dan akan dapat diterapkan nantinya dalam kehidupan sehari-hari. Berbeda dengan pembelajaran IPA yang menggunakan pembelajaran Konvensional, selama proses pembelajaran siswa terlihat kurang aktif. Proses pembelajaran masih berpusat pada guru (teacher centre) yang lebih banyak memberikan ceramah daripada kegiatan yang melibatkan siswa secara aktif dalam proses pembelajaran hal ini dapat mengakibatkan kompetensi pengetahuan IPA siswa kurang optimal.

Hasil penelitian ini mendukung hipotesis yang menyatakan bahwa terdapat pengaruh yang singnifikan kompetensi pengetahuan IPA pada siswa kelas IV SD Gugus I Gusti Ngurah Rai Denpasar Tahun Ajaran 2017/2018. Pembelajaran dengan menggunakan model pembelajaran generatif berbasis lingkungan memberikan pengaruh yang lebih baik terhadap proses dan hasil pembelajaran kompetensi pengetahuan IPA dibandingkan dengan pembelajaran konvensional.

Pemilihan model pembelajaran yang tepat dapat berpengaruh terhadap kompetensi pengetahuan siswa. Penggunaan model pembelajaran generatif berbasis lingkungan berdampak positif terhadap pembelajaran di sekolah yaitu siswa tidak hanya mendengar keterangan guru tetapi dapat berperan aktif untuk menggali, menganalisis, mengevaluasi pemahaman siswa terhadap konsep yang dipelajari serta siswa dapat menjadi lebih komunikatif dalam proses pembelajaran. Proses pembelajaran ini juga memberikan dampak terhadap siswa yaitu siswa lebih aktif dalam pembelajaran sehingga kemampuan analisis, evaluatif dan argumentatif siswa dapat berkembang dan meningkatkan secara signifikan. Serta perpaduan dengan media lingkungan yang membuat pelajaran lebih aplikatif, maksudnya materi belajar yang diperoleh siswa melalui media lingkungan kemungkinan besar akan dapat diaplikasikan langsung, karena siswa akan sering menemui benda - benda atau peristiwa serupa dalam kehidupannya sehari hari sehingga memberikan pengaruh yang lebih baik terhadap kompetensi pengetahuan IPA siswa.

Oleh karena itu, model pembelajaran generatif berbasis lingkungan dapat dijadikan model dan media pembelajaran alternatif bagi guru, sekolah maupun peneliti lainnya dalam menciptakan pembelajaran yang lebih menyenangkan untuk memberikan hasil yang baik terhadap kompetensi pengetahuan IPA siswa, sehingga siswa tidak hanya dapat memahami materi yang dipelajari tetapi dapat menggunakan atau mengaplikasikan dalam kehidupan sehari-hari. Hal ini menunjukkan bahwa model pembelajaran yang diterapkan memberikan pengaruh terhadap kompetensi pengetahuan siswa sehingga penyelenggaraan pendidikan diharapkan agar lebih memperhatikan model yang digunakan dalam pembelajaran.

Dalam pelaksanaan model pembelajaran generatif berbasis lingkungan diharapkan adanya upaya perbaikan dalam pengorganisasian siswa saat melaksanakan proses pembelajaran sehingga dapat menciptakan pembelajaran yang lebih kondusif dan efektif.

\section{Simpulan dan Saran}

Berdasarkan hasil analisis dengan menggunakan uji-t diperoleh thitung $=3,507$. Harga tersebut kemudian dibandingkan dengan harga ttabel dengan $\mathrm{dk}=63$ pada taraf signifikansi 5\% ttabel $=2,000 \mathrm{ini}$ berarti bahwa terdapat pengaruh yang signifikan model pembelajaran generatif berbasis lingkungan terhadap kompetensi pengetahuan IPA pada siswa kelas IV SD Gugus I Gusti Ngurah Rai Denpasar Tahun Ajaran 2017/2018. Selain itu dari rata-rata kelompok eksperimen $=51,84>=33,78$ dari kelompok kontrol. Sehingga dapat disimpulkan bahwa model pembelajaran generatif berbasis lingkungan berpengaruh terhadap kompetensi pengetahuan IPA siswa kelas IV SD Gugus I Gusti Ngurah Rai Denpasar Tahun Ajaran 2017/2018.

Adapun saran yang disampaikan sebagai berikut, Kepada Guru Berdasarkan temuan penelitian yang diperoleh, disarankan kepada guru agar lebih kreatif untuk memberikan fasilitas berupa sumber belajar dan kesempatan yang lebih besar bagi siswa pada pembelajaran dengan menggunakan model pembelajarangeneratif berbasis lingkungan sehingga tercipta pembelajaran bermakna dan 
menyenangkan bagi siswa, Kepada Sekolah Berdasarkan temuan penelitian, disarankan kepada kepala sekolah agar dapat menggunakan hasil penelitian ini sebagai pendukung sumber belajar guru dalam meningkatkan kualitas pembelajaran dengan menciptakan pembelajaran yang menyenangkan di sekolah sehingga sekolah mampu menghasilkan siswa yang berkualitas, Kepada Peneliti Lain. Berdasarkan temuan penelitian, disarankan kepada peneliti agar hasil penelitian ini digunakan sebagai referensi untuk melaksanakan penelitian selanjutnya atau menemukan inovasi kegiatan pembelajaran lainnya yang bermakna dan menyenangkan bagi siswa.

\section{Daftar Rujukan}

Agung, A.A. Gede. 2014. “Metodologi Penelitian Pendidikan”. Singaraja : Aditya Media Publising

Agung Adiputri. 2014. "Pengaruh Penerapan Model Pembelajaran Generatif Berbasis Bekerja Ilmiah Terhadap Hasil Belajar IPA Siswa Kelas V SD Gugus Mayor Metra Denpasar". e-Journal PGSD Universitas Pendidikan Ganesha Jurusan PGSD (Vol. 2). Tersedia pada

https://ejournal.undiksha.ac.id/index.php/JJPGSD/article/view/2445. Diakses pada tanggal 1 Februari 2018.

Arikunto, Suharsimi. 2015. “Dasar-Dasar Evaluasi Pendidikan ”. Jakarta: Bumi Aksara.

Ayu Wulandari. 2013. "Pengaruh Model Pembelajaran Generatif Terhadapp Minat Dan Hasil Belajar IPA Pada Siswa Kelas IV SD (Studi Kasus Di Gugus Letkol Wianu Denpasar Utara). e-Journal Program Pascasarjana Universitas Pendidikan Ganesha Program Studi Pendidikan Dasar (Volume 4). Tersedia pada https://media.neliti.com/media/publications/123793-ID-pengaruh-model-pembelajarangeneratif-te.pdf. Diakses pada tanggal 1 Februari 2018.

BSNP. 2006. Standar Isi untuk Satuan Pendidikan Dasar dan Menengah. Jakarta: Badan Standar Nasional Pendidikan

Budi Wijaya. 2014. "Pengaruh Model Pembelajaran Generatif Terhadapp Keterampilan Berpikir Kreatif Dan Keterampilan Proses Sains". e-Journal Program Pascasarjana Universitas Pendidikan Ganesha Program Studi Pendidikan Dasar (Vol. 4). Tersedia pada http://pasca.undiksha.ac.id/ejurnal/index.php-jurnal_ipa/article/view/1296. Di akses pada tanggal 30 Januari 2018.

Darmadi, Hamid. 2013. Metode Penelitian Pendidikan. Bandung:Alfabeta.

Daryanto. 2014. “Pendekatan Pembelajaran Saintifik Kurikulum 2013”. Yogyakarta: Gava Media

Indah Purwanti. 2014. "Model Pembelajaran Generatif Berbasis Lingkungan Sekolah Berpengaruh Terhadap Hasil Belajar IPA Siswa Kelas V SD Gugus 1 Abiansemal.". e-Journal PGSD Universitas Pendidikan Ganesha Jurusan PGSD (Vol. 2). Tersedia pada https://ejournal.undiksha.ac.id/index.php /JJPGSD/article/view/1881. Diakses pada tanggal 1 Februari 2018.

Jakni. 2016. Metodologi Penelitian Eksperimen Bidang Pendidikan. Bandung:Alfabeta.

Ketut Neka. 2015. “Pengaruh Model Pembelajaran Inkuiri Terbimbing Berbasis Lingkungan Terhadapp Keterampilan Berpikir Kreatif Dan Penguasaan Konsep IPA Siswa Kelas V SD Gugus VIII Kecamatan Abang". e-Journal Program Pascasarjana Universitas Pendidikan Ganesha Program Studi Pendidikan Dasar (Vol. 5). Tersedia pada http://pasca.undiksha.ac.id/e-jurnal/index.phpjurnal_ipa/article/view/1489. Di akses pada tanggal 30 Januari 2018.

Kosasih. 2014. "Strategi Belajar dan Pembelajaran Implementasi Kurikulum 2013". Bandung: Yrama Widya.

Koyan, I Wayan. 2012. "Statistika Terapan (Teknik Analisis Data Kuantitatif)". Singaraja: Universitas Pendidikan Ganesha.

Mulyasa, H.E. 2015. Pengembangan dan Implementasi Kurikulum 2013. Bandung. PT. Remaja Rosdakarya.

Samatowa,Usman.2016. "Pembelajaran IPA di Sekolah Dasar". Jakarta Barat: Permata Puri Media. 
Setyosari, Punaji. 2015. "Metode Penelitian Pendidikan \& Pengembangan ". Jakarta: Kencana Prenada Media Group.

Suastra.2017.Pembelajaran Sains Terkini Mendekatkan Siswa dengan Lingkungan Alamiah dan Sosisal Budayanya. Singaraja:Universitas Pendidikan Ganesha

Sudijono, Anas. 2013. “Pengantar Evaluasi Pendidikan”. Jakarta: Rajawali

Sugiyono. 2012. "Metode Penelitian Kuantitatif Kualitatif dan R\&D”. Bandung: Alfabeta.

Sugiyono. 2017. “Metode Penelitian Kuantitatif Kualitatif dan R\&D”. Bandung: Alfabeta.

Sugiyono. 2012. "Statistika untuk Penelitian". Bandung: Alfabeta.

Susanto, Ahmad. 2013. "Teori Belajar dan Pembelajaran di Sekolah Dasar ". Jakarta: Prenada Media Group.

Suyatno. 2015. Menjelajah Pembelajaran Inovatif. Sidoarjo: Masmedia Buana Pustaka.

Wena, Made. 2014. Strategi Pembelajaran Inovatif Kontemporer. Jakarta: Bumi Aksar.

Wulandari, I Gusti Agung Ayu, Nyoman Dantes, Nyoman Tika. 2014. Pengaruh Model Pembelajaran Generatif Terhadap Minat Dan Hasil Belajar IPA Pada Siswa Kelas V SD (Studi Kasus Di Gugus Letkol Wisnu Denpasar Utara). e-Journal Program Pascasarjana Universitas Pendidikan Ganesha Program Studi Pendidikan Dasar Volume 4.

Yani, Monica Fitri , Yurnetti, Gusnedi. 2016. Pengaruh Penerapan Model Generative Learning Terhadap Pencapaian Kompetensi Ipa Siswa Kelas VIII SMP N 7 Padang. PILLAR OF PHYSICS EDUCATION, Vol. 8, hal: 65-72

Yusuf, Muri. 2015. Asesmen dan Evaluasi Pendidikan: Pilar Penyedia Informasi dan Kegiatan Pengendalian Mutu Pendidikan. Jakarta: Prenadamedia Group. 